\title{
Trama terapêutica: um estudo sobre a (re)constituição da identidade de usuários de drogas $^{1}$
}

\author{
J JACQUELINE SCHNEIDER
}

\begin{abstract}
resumo Este trabalho aborda experiências de usuários de drogas desdobradas em instituiçôes localizadas na Grande Curitiba, no estado do Paraná, que se pautavam pela lógica absenteísta: Igreja do Santo Daime Céu da Nova Vida, Comunidade Terapêutica Água da Vida e um grupo da Associação dos Alcoólicos Anônimos. A partir de experiência etnográfica, aponto que esses locais envolvem características idiossincráticas, representações e sociabilidades que póem em curso, através de agenciamentos terapêuticos, a construção de uma “identidade de dependente químico” e, com maior ou menor sucesso, a "incorporação de um habitus". Como desdobramento desse processo, sugiro que essas experiências se inclinam à metamorfose, definindo modos de ser/estar no mundo, viabilizada pelo engajamento dos sujeitos com o que compreendemos como projetos terapêuticos.
\end{abstract}

palavras-chave Drogas. Terapêutica. Experiência. Identidade. Metamorfose.

\section{O fenômeno das drogas}

Em sociedades como a nossa, o que convencionamos chamar de drogas corresponde ao que muitos especialistas voltados à temática preferem chamar de substâncias psicoativas. Substâncias, por sua vez, capazes de atuar sobre o sistema nervoso, sobre o que entendemos por psique, sobre a dinâmica neural e, assim, capazes de alterar a consciência humana atra- vés da manipulação corporal. Carneiro chama a atenção para a existência de uma "ubíqua e contínua presença das drogas em cada cultura e de uma imensa rede de significados culturais, ritos e práticas de socialização nelas consubstanciadas" (2005, p. 17). Neste sentido, o autor esclarece que tanto o conceito droga quanto o conceito vício são polissêmicos na sociedade contemporânea, constituídos historicamente, adquirindo apenas recentemente a edificação de um paradigma do abuso de drogas.

Trata-se da construção de um fenômeno que marca a sua presença através da pauta política e de intensos debates nas esferas jurídica e médica e, dessa forma, a representação do que podemos chamar de "fenômeno das drogas" acentua-se a partir da criminalização e da medicalização do consumo (Vargas, 2001; 2005). Com efeito, esses processos tornaram-se formas de relevância densa atuantes na elaboração das experiências de atores sociais que, de alguma forma, constituem o contexto das drogas. Devido a essas características, como uma resposta a possíveis eventos tornados perturbatórios por envolverem o uso de drogas, as trajetórias e os itinerários desses atores muitas vezes cruzam instituiçóes específicas que se organizam a partir da medicalização do consumo,as quais seguem a lógica absenteísta ${ }^{2}$.

Este trabalho discute repercussôes dessa lógica particular na experiência, percepção e orientação de pessoas que se encontram em ins- 
tituiçóes que a partir dela se organizam. Com este objetivo, apresento em um primeiro momento a trajetória percorrida entre os espaços institucionais e suas organização e estrutura. Em seguida, discuto características que as aproximam e as distanciam e que definem representaçóes centrais que organizam as experiências dos sujeitos. Dando continuidade, apresento modelos de sociabilidade e dinâmicas específicas vivenciadas nos contextos institucionais que viabilizam essa organização e que a definem como construção de uma identidade.

\section{Trajetória de campo, instituiçóes e aspectos metodológicos}

Neste trabalho, parto de uma experiência etnográfica realizada na regiáo da Grande Curitiba, no estado do Paraná, em instituiçôes que constituem diferentes "modalidades" 3 para o tratamento de usuários de drogas: o Centro de Recuperação Água da Vida (Cravi), que se encaixa no modelo de "comunidade terapêutica"; a Igreja do Santo Daime Céu da Nova Vida (ICNV), localizada no município de Pinhais, na Grande Curitiba; e um grupo da associação de anônimos - os Alcoólicos Anônimos (AA). A escolha desses locais pautou-se pela acessibilidade, concordância dos dirigentes com a realização da pesquisa e por critérios de variedade dos recursos terapêuticos, procurando focar-se nos sujeitos e nas possíveis diferenças entre os relatos que poderiam emergir a partir de localizaçôes específicas.

As comunidades terapêuticas integram o fenômeno das drogas como uma das possibilidades para aqueles usuários que se direcionam ou são direcionados a tratamentos e intervençóes específicos no aspecto de uso de drogas; constituindo o contexto de opçóes que se oferece para atuar nessa especificidade conjuntamente com terapias como a psiquiatria, a psicoterapia analítica, a prevenção à recaída, etc.. São regulamentadas pela Agência Nacional de Vigilância Sanitária e pela Secretaria Nacional de Políticas sobre Drogas e são sistemas estruturados com regras, limites claros e afetos controlados através de responsabilidades, normas e horários (Sabino; Cazenave, 2005).

A comunidade terapêutica Cravi abrange uma casa feminina localizada na cidade de Curitiba; um escritório, local onde se fazem os trabalhos administrativos, o primeiro encontro com potenciais residentes e/ou seus familiares e determinados grupos terapêuticos; e uma casa masculina, em um sítio em Almirante Tamandaré, município integrante da Grande Curitiba. Nessa comunidade o "programa de tratamento" consiste em um período de seis meses de "internação", termo nativo que também se refere à residência das pessoas no local, chamadas de "residentes". Este programa é dividido em estágios através dos quais a pessoa atinge e passa ao seguinte, conforme o seu processo de recuperação. $\mathrm{O}$ número de residentes varia bastante, mas conforme percebi com o passar do tempo, apresenta uma média aproximada de 70 a 80 pessoas nos dois espaços de internação, com uma rotatividade ainda mais variável.

Os participantes do AA se consideram uma irmandade de pessoas que, através do compartilhamento de experiências realizado principalmente em reuniôes, busca resolver o problema comum da "doença do alcoolismo". Há muitos grupos de AA em atuação em países e cidades, assim como por toda a região da Grande Curitiba. A minha pesquisa se realizou com um grupo pequeno, de aproximadamente cinco pessoas, na Igreja Bom Jesus, uma das regióes centrais da cidade de Curitiba, selecionada pela facilidade de acesso que me oferecia.

A instituição que mais se diferencia das recém-mencionadas é a Igreja do Santo Daime Céu da Nova Vida. Santo Daime é uma expressão multivocal e, assim, pode se referir 
a um movimento religioso e ao nome dado à substância psicoativa na forma de bebida ingerida durante os rituais (De Rose, 2006). Essa bebida, conhecida pelo nome de ayahuasca, é produzida pela cocçáo de duas plantas oriundas da floresta amazônica: o "cipó jagube" e a "folha rainha". De acordo com a autora, "esta bebida é considerada como um 'ser divino', dotado de personalidade própria e capaz de curar e de transmitir conhecimento" (p. 35).

A igreja está localizada em meio urbano, em uma área residencial, ocupando uma casa bastante ampla, pintada de verde e com grandes letreiros com o seu nome. Este grupo é significativamente diferenciado de outros grupos daimistas, cujos relatos eu conhecia principalmente por não circunscrever uma comunidade de pessoas que residiam no próprio local e não possuir vínculo com nenhuma das vertentes da religiãó ${ }^{4}$. Os coordenadores da ICNV reconhecem uma diferença entre essa igreja $e$ outras que compartilham do uso da ayahuasca, a qual se refere ao trabalho direcionado para a cura da "dependência química". Embora ela esteja aberta para que as pessoas participem em trabalhos que acontecem duas vezes por mês, segundo a fala de todos com os quais conversei e que ocupam papéis centrais no contexto, a instituição possui a característica de ser voltada para a cura de "dependentes químicos".

Conforme os relatos, a ICNV se encontra propositalmente no meio urbano para que os "dependentes" tenham acesso mais fácil a ela. Além disso, o padrinho5 comenta: "não temos nada pra esconder", referindo-se ao preconceito que relata perceber em relação à própria religião, principalmente por conta da ingestáo da bebida chamada pelo grupo de "sacramento do Santo Daime", ou simplesmente "sacramento do Daime", o qual, neste contexto específico, refere-se à ayahuasca. Alegam também que a igreja tem a característica de realizar obra social "principalmente para aqueles dependentes que não podem pagar clínicas e psicólogos”, de acordo com o relato do padrinho. Os rituais específicos voltados aos usuários de drogas são nomeados "trabalhos de cura" e acontecem uma vez por semana. Para participar as pessoas devem realizar uma "triagem" - basicamente questionamentos sobre sua intençáo e o que as levou até a igreja - com o padrinho ou com outro líder da igreja.

Durante a investigação, registrei um conjunto de narrativas coletadas em situaçóes de entrevista, nas quais eu procurava interferir o mínimo possível, fornecendo apenas casualmente incentivos às próprias falas dos sujeitos. Com o objetivo de estudar os desdobramentos das experiências desses sujeitos nesses locais específicos, reproduzo algumas narrativas, descrevo situaçóes do quotidiano e chamo ao diálogo diversos sujeitos ${ }^{6}$ que constituíram a experiência etnográfica.

\section{Aproximaçóes, distanciamentos e encontros entre as instituiçóes}

\section{Aproximaçóes: projetos e tramas terapêuticas}

Embora as instituiçôes apresentem peculiaridades nos mais diferentes setores - cujos traços mais relevantes serão explorados adiante -, o horizonte comum fundamental refere-se às orientações que visam à recuperação do dependente químico, baseadas em um incentivo à prática da abstinência. $A$ abstinência pode ser tomada "como elemento de uma terapêutica e como princípio organizador de um modo de vida e de um sistema de valores, indissociável de um contexto patológico" (Faizang, 1992, p. 7, tradução minha). De acordo com Campos (2003), a abstinência deve ser entendida, sobretudo, como um princípio organizador da própria existência. Dessa forma, pode-se falar em uma "cultura da abstinência", um sistema simbólico atuante como organizador da exis- 
tência e de um modo de vida. A partir dessa cultura, os contextos terapêuticos jogam náo apenas com a noção da "doença" da dependência química, mas, densamente, com o "ser dependente químico".

Terapias são veículos através dos quais tipos específicos de determinadas experiências são definidos e tomam formas culturalmente reconhecidas (Young, 1976), fornecendo ao sujeito uma perspectiva coerente para a apreensão subjetiva de sua trajetória pessoal, propiciando um parâmetro identitário (Figueira, 1978). As instituiçôes podem ser percebidas como articuladoras das experiências e produtoras de sentido para as perturbaçóes que envolvem uso de drogas. Dessa forma, o código cultural atuante nas instituiçốes terapêuticas condensa idiomas e referentes capazes de fornecer linguagens específicas para que um indivíduo articule dimensôes da experiência e reinterprete-a com novos significados.

Dessa forma, um sistema terapêutico pode ser compreendido como um campo simbólico, como província de significados constituinte do que Gilberto Velho (2003) chamou de "sociedades complexas". No estudo de sociedades como essas, insere-se uma problemática no que concerne às trajetórias pessoais dos indivíduos, que se define como um jogo entre "unidade" e "fragmentaçáo". Essa dinâmica está associada à permanente latência nas fronteiras entre essas províncias, supondo um potencial de "metamorfose". A metamorfose "possibilita, através do acionamento de códigos associados a contextos e domínios específicos - portanto, a universos simbólicos diferenciados - que os indivíduos estejam sendo permanentemente reconstruídos" (Velho, 2003, p. 29).

A partir das trajetórias pessoais entre os domínios de realidade, redefinem-se "projetos" através do trânsito e da orientação em um "campo de possibilidades". Este campo se configura como espaço para a implementação e formulação de projetos que, em nível individual, "lidam com a performance, as exploraçóes, o desempenho e as opçóes, ancoradas a avaliaçôes e definiçóes da realidade" (Op. cit., p. 28). Já a noçáo de campo de possibilidades pode ser compreendida como uma determinada realidade social negociada, informada pelos paradigmas culturais compartilhados. Contudo, a noção de projeto não se atém exclusivamente ao nível individual e pode ser desdobrada em uma noçáo de projetos coletivos, emergida a partir de um olhar particular para as instituiçôes terapêuticas elencadas nessa discussão.

Estas instituiçôes, na medida em que se inserem no amplo contexto das drogas como propiciadoras de metamorfose para os usuários que nelas se colocam, configuram-se como um projeto que se estabelece a partir de um código cultural específico, capaz de reorganizar tanto as experiências de perturbação quanto oferecer parâmetros identitários. Por conseguinte, pode-se entender que as instituiçóes atuam como projetos terapêuticos articuladores de um código específico de identidade, pois estabelecem e aglutinam valores, organizando-se de forma a se estabelecerem como projetos disponíveis no "campo de possibilidades" que compóe o fenômeno das drogas, estabelecendo códigos próprios para a reconstituição de projetos pessoais.

Neste sentido, tornam-se menos visíveis as fronteiras entre a Cravi, a ICNV e o AA. Essas instituiçóes atuam como agenciamentos terapêuticos, ou seja, são agenciadoras de um projeto de identidade construído a partir das representaçóes sociais vigentes em torno do fenômeno das drogas. Nesta direção, a prática da abstinência está vinculada a um código específico da "doença da dependência química". Essa similaridade em concepçóes centrais implica um entrecruzamento com as representaçóes definidas pelo monopólio da interpretação biomédica - que define a noção de dependência de drogas e a insere no amplo espectro das 
doenças mentais, as quais, em última análise, são determinadas por uma epistemologia fisicalista, não possuem cura e, assim, estão sempre dispostas à reincidência e à progressão.

O que em nossa sociedade chamamos de doença é uma construção sociocultural e subjetiva e, assim, náo pode ser reduzida a manifestaçóes biológicas (Langdon, 2003). Ou seja, categorias como "saúde" e "doença" são relacionais e devem ser desnaturalizadas. Neste sentido, experiências que compóem as trajetórias de vida são reinterpretadas através da noção de doença que é mais densamente compartilhada nas instituiçôes terapêuticas, em um esforço geral de conhecimento, "identificar" sintomas e decodificar sua articulação específica como "doença". Portanto, há uma relação entre os projetos terapêuticos aqui analisados e o modelo hegemônico de atenção à saúde. Contudo, embora esses projetos operem com o discurso da dependência química estabelecido pelo modelo dominante, também negociam práticas e significantes e, assim, a representação hegemônica encontra uma repercussão densa, principalmente porque evoca e desdobra efetivamente as experiências vividas para os idiomas locais.

Com efeito, nessas instituições há uma série de peculiaridades que náo correspondem exatamente aos paradigmas da biomedicina e que estruturam suas representaçóes. Inicialmente considero o aspecto da espiritualidade. Nas representaçóes da Cravi, compreende-se a "dependência química" como uma doença da ordem "biopsicossocioespiritual" e há assembleias religiosas em algum dia do fim de semana em que podem participar os familiares dos residentes, assim como também faz parte do programa uma prática em que um pastor evangélico reúne residentes para cantar hinos de louvor e estudar o evangelho; enquanto na ICNV trata-se de um sistema propriamente religioso, e, no AA, o Poder Superior foi evocado na reunião em que participei e, conforme os participantes me explicaram, trata-se de reconhecer um poder espiritual.

$\mathrm{O}$ aspecto da espiritualidade presente em algumas narrativas ocupa um papel importante para a "recuperação": "se eu for pegar minha relação com Deus, na forma que eu vivo, dentro do meu estilo cristáo, foi essencial, pra me centralizar na minha vida, eu acredito muito nisso"; diz Cláudio, um homem que havia sido usuário de diversas drogas por mais de duas décadas, experimentou uma série de tratamentos e encontrava-se na atualidade da pesquisa como coordenador de grupos terapêuticos na Cravi, instituição na qual, segundo seu relato, conseguiu controlar sua dependência química.

Sandro, teólogo e missionário que foi usuário de cocaína e direcionado pela igreja na qual trabalhava para tratamento em comunidades terapêuticas logo que foi descoberto, atualmente é coordenador do "Serviço de Orientação Espiritual” da Cravi:

Sou eu que faço circular entre as famílias e os residentes o valor do amor de Deus [...], aqui na comunidade eu entendo assim que nós somos quase um modelo da igreja primitiva, dos apóstolos, onde tinham todas as coisas em comum, e perseveravam, unânimes, na oração e na busca. Então hoje nós temos aqui tudo em comum, né, comemos as mesmas coisas, dormimos no mesmo padrão de alojamento, é... E temos o problema da dependência química vigente.

Evocando uma fala em sentido próximo, Anderson, padrinho da ICNV, após treze anos de drogadicção ativa de cocaína e álcool, curou-se em uma igreja do Santo Daime. Após a realização da cura, frequentou assiduamente a igreja onde o fato se deu. De acordo com o relato de seu pai, que o acompanhou em todo o trajeto, seu filho recebeu um chamado para abrir a "casa" que agora coordena. Anderson explicou que, de acordo com sua experiência 
pessoal e o compartilhamento da experiência de outros que tiveram os mesmos problemas que ele, o Santo Daime "dá rapidamente a transformação", tornando a pessoa "extremamente responsável e cumpridora de suas obrigaçóes sociais". Essa pessoa, assim como outros com os quais dialoguei, passou por uma gama de instituiçóes terapêuticas: "desde acupuntura até comunidade terapêutica. Mas o que estava faltando mesmo era a espiritualidade", dimensão encontrada e principalmente trabalhada no Santo Daime.

Nota-se, a partir desses relatos, uma centralidade significativa da noção de espiritualidade que, contextualizada e num processo de constante e mútua decodificação, é uma espécie de critério estruturador das interpretaçôes dos interlocutores. Assim, as referências à dimensão espiritual trazidas pelos sujeitos podem indicar pistas para pensarmos a eficácia da "apropriaçáo" do projeto terapêutico e, assim, da articulação da experiência, na maneira como é trazida por alguns interlocutores. Para Rabelo (1993), a experiência religiosa cura ao proporcionar uma "ordem" em relação à "desordem" da pessoa. Nesse sentido, o desvendamento de uma dimensão espiritual permite a obtenção de um sentido significado simbolicamente (Montero, 1985). Portanto, podemos entender as experiências religiosas e sua dimensão espiritual como elementos importantes para a articulação das experiências do que tem sido considerado como a doença da dependência química.

Outra característica peculiar é o número significativo de agentes sociais "dependentes químicos" que se encarregam dos mais diversos procedimentos no interior das instituiçóes. São pessoas "recuperadas" nas terapêuticas em que estão atuando. Na Cravi, os "monitores", supervisores do quotidiano e pessoas que desempenham outros papéis no funcionamento institucional. É o caso de Cláudio, já citado, um dos meus interlocutores-chave e atual "téc- nico em dependência química”, coordenador de uma variedade de grupos realizados na Comunidade e palestrante em diversos espaços extrainstitucionais sobre o que consideram e como definem essa dependência; Diana, por anos usuária de cocaína e crack, que foi levada pela família para o tratamento na Cravi após um episódio de overdose, local onde realizou todo o programa de tratamento e conheceu Cláudio, seu atual companheiro, inserindo-se como ele no grupo de pessoas que organizam a instituição, atualmente como auxiliar financeira; e o próprio pastor Flávio, fundador e principal dirigente, que vem de uma história de 25 anos de uso de cocaína injetável.

$\mathrm{Na}$ ICNV, o padrinho Anderson, como já mencionei; Lorenço, uma das pessoas que ocupa um papel central na igreja, ex-usuário de maconha, álcool e cocaína em períodos diferentes de sua vida por aproximadamente 20 anos; e os "fiscais" participantes da igreja, periodicamente convocados às funçóes especiais nos trabalhos rituais de supervisão, assistência e organização:

A grande maioria. Principalmente entre os homens aí a gente pode dizer que o percentual aí é de $70 \%$ aí praticamente veio de histórico de drogadição, de alcoolismo né, entre as mulheres esse número já não é tão grande, a maioria delas é ou esposa, mas também tem algumas que vieram desse caminho (Anderson).

O AA, por sua vez, embora não apresente uma segmentação nítida como nas outras duas instituiçóes entre os usuários que já alcançaram a recuperação e que coordenam/supervisionam e aqueles que ainda não a alcançaram, é um grupo estruturado e gerido pelos próprios "alcoólicos em recuperaçáa”. Quanto ao aspecto da segmentaçáo, as funçóes de controle e orientação de um grupo sobre o outro é mais difusa e aparentemente não encontra destaque no 
estabelecimento de relaçóes verticais. Existe, contudo, um escalonamento entre aqueles que estão abstinentes por longos períodos de tempo e que geralmente inspiram aqueles que estão ingressando.

Assim como no trabalho de Montero (1985) sobre a umbanda, há continuidade entre o lugar daquele que cura e daquele que está doente. Dessa forma, é essa especificidade que legitima a proposta das pessoas do ato de curar. Para a autora, o poder dos curadores está fundado no fato de terem vivido experiências similares às daqueles cuja cura se propóem a efetivar. Cravalho (1998), explorando a complexidade que se revela nas relaçóes entre sistemas socioculturais e saúde mental, faz um estudo de caso a respeito de uma figura social, sugerindo sua alocação em um estado de "transitividade" no qual não se define completamente o papel social de curador e o papel social de doente. Em sentido próximo, Caprara (1998) refere-se ao conceito de "médico ferido", relacionado a uma visão no interior da biomedicina que diz respeito, na verdade, a um conceito elaborado em diferentes culturas: "a dupla polaridade de figura doente com poderes de cura” (p. 124), trazendo com ela os signos da cura e da doença.

Em sentido próximo, os interlocutores mencionados conforme as descriçôes acima podem ser abordados como figuras transitivas por trazerem consigo o que Caprara chamou de "signos da doença", e da possibilidade de recuperação, pois se situavam como a corporificaçáo de um "projeto que constantemente se projeta", atuando como a possibilidade incorporada de se abandonar não apenas o uso de drogas, mas a vida que com elas se tramava. Como modelos de projetos bem-sucedidos, sugerem evidências concretas para novas possibilidades de ser na vida, que se abrem no engajamento com as instituições. Essas diferentes posiçôes ocupadas pelos "transitivos" indicam uma gama de diferentes perspectivas de outros projetos. Por conseguinte, há uma dinâmica interessante no jogo projeto/campo de possibilidades movimentado por esses "exemplos".

Assim, na medida em que projetos de sucesso, de superação e até mesmo de "heroísmo" ou "bondade social" interagem com as pessoas recém-chegadas, marcadas por uma fragmentaçáo decorrente de eventos tornados perturbatórios, tornam-se veículos para essas pessoas se submeterem e se aceitarem como dependentes químicas, atuando como facilitadores dos processos de aceitação e reconhecimento como tal. Da mesma forma, o compartilhamento de experiências comuns e vivências passadas de uso de drogas sáo elementos cruciais para a legitimação tanto de um sujeito recém-chegado quanto do outro transitivo recuperado, bem como de suas respectivas posiçóes no interior dos projetos terapêuticos. Para essas legitimações, as figuras transitivas atuam também como uma presença que aceita e compreende experiências não legitimadas em outros contextos, como se percebe na fala de Sandro:

É, eu vejo assim, que o grande apoio que a gente recebe é de pessoas que conhecem a situação. E pessoas que náo viveram, não experienciaram a dependência química, elas te apoiam até determinado momento, depois de um tempo elas dão as costas, inclusive esposa, mãe e pai, a grande verdade é essa. As pessoas que já tiveram envolvimento, elas sabem como é a dor, né, entâo eu tenho apoio do pessoal aqui da Cravi, [...] faço análise com o pastor, que foi usuário 25 anos de cocaína injetável.

Finalizando a discussão das características peculiares e comuns a todas as instituiçóes estudadas, tomo em consideraçáo uma rede semântica peculiar que se apresentou tanto nos discursos institucionais quanto nas narrativas pessoais: "fundo do poço", "perdas", "droga de preferência" e, inclusive, suas categorias 
aglutinadoras: "dependência/dependente químico", "doença", entre outras semelhantes. Byron Good (1977), em seu estudo sobre "heart distress", demonstra a existência de uma rede semântica específica, aglutinadora de um léxico que revela uma doença constituída socioculturalmente. Essa categoria de doença era principalmente expressão de questôes sociais de cunho hierárquico, ligadas à relação entre homens e mulheres. Neste sentido, as relações entre categorias de doenças e redes semânticas nos ajudam a evidenciar os caminhos pelos quais fatores sociais e culturais determinam "perturbações".

Becker (2004) menciona que o modo através do qual são chamadas as coisas reflete irremediavelmente relaçóes de poder ${ }^{7}$. Ou seja, as pessoas têm de se ajustar. A perspectiva de Becker deve ser considerada seriamente e a apropriação de categorias vinculadas a uma rede semântica tal como "doença", "dependência química”, "dependente químico" e outras categorias a ela associadas, como "fundo do poço", "perdas", entre outras, são demonstrativas da incorporaçáo de um determinado tipo de articulação do discurso em contextos locais de poder. Assim, as palavras vão moldando as interpretaçóes e as próprias experiências pessoais, contornando, em conjunto com os outros aspectos, organizaçóes coletivas de experiências que se dão no nível da aceitação e interpretação comuns dos sujeitos a respeito de si mesmos.

\section{Distanciamentos e encontros: particularida- des institucionais e a noçáo de cura ${ }^{8}$}

Embora as instituiçóes apresentem as proximidades descritas acima, é preciso considerar suas diferenças. A Igreja do Santo Daime Céu da Nova Vida apresenta-se como o exemplo mais acentuado de distanciamento. "Santo Daime”, como já mencionado, é uma categoria que remete a grupos religiosos específicos, os quais se distinguem pelo uso ritual do enteógeno9 ayahuasca. Groisman e Sell (1996), em um estudo numa comunidade daimista em Florianópolis/SC, argumentam a respeito da efetividade do que chamam de "sistema de cura do Daime" (Daime healing system), a partir de um processo estrutura-desestrutura-reestrutura que envolve a circulação intensa e extensa na vivência cotidiana de valores, expectativas e procedimentos que se convertem em um sistema, argumentando principalmente sobre a verificação de uma "eficácia terapêutica”. Groisman (2009), revisitando esses dados etnográficos, fala sobre a "cultura da cura", referindo-se à presença nos discursos dos participantes fundamentados em experiências pessoais reconhecedoras do "poder terapêutico" da bebida.

Em relação à eficácia terapêutica, tomei conhecimento de uma importante distinção a ser assinalada em uma conversa que tive com Lorenço. Este interlocutor comentou que já estava parando aos poucos com o uso de drogas, mas um amigo que as usava em sua companhia e que havia feito sua cura no Santo Daime levou-o para participar de um trabalho de cura. A partir dessa experiência nunca mais usou drogas e permanece vinculado à igreja até então. Questionado a respeito dela, Lorenço respondeu:

Fiz um trabalho de cura e realmente parei, foi um gatilho pra disparar essa vontade de parar, de dar um fim nessa utilização de drogas. Entáo faz quase 6 anos que náo uso drogas de espécie alguma, nem álcool, nem cigarro, nada. [...] Ah... terrível né [referindo-se a este específico trabalho de cura], cada um passa a sua experiência, eu até não gosto de falar muito sobre isso, essa experiência com o sagrado, com o divino pra mim foi muito significativa, que cada um fica marcado, né, e pessoas que náo passam por essa experiência com o divino não conseguem a 
cura, é um despertar, fisicamente, é bastante difícil, mexe bastante. E com o pensamento... foi interessante, foi um ponto de partida excelente para se processar toda essa mudança.

Segundo Lorenço, o "encontro com o divino" é um "presente", uma "experiência íntima", fundamental para que a cura se processe. De acordo com o relato dos interlocutores, a experiência de cura, desdobrada pela ingestão da bebida do Santo Daime, configura um momento de introspecção profunda, no qual a pessoa deve necessariamente interagir com divindades do plano espiritual, interação cujo caráter é específico a cada pessoa, mas que frequentemente abarca instruçóes e desvendamento de aspectos escondidos da existência do próprio sujeito, que o induzirão a uma transformação e, por conseguinte, à cura. Essa experiência curativa, portanto, deve acontecer em um momento circunscrito. Unindo-se a essa característica, o encontro com o divino deve acontecer na primeira ingestão da bebida e somente nessa vez: depois dessa experiência, a pessoa estabeleceria mecanismos que impediriam outras ocorrências, novamente segundo as explicaçóes de Lorenço, por não ser esta uma experiência que deva acontecer com frequência.

O fato aparentemente paradoxal de se tratar o uso de substâncias psicoativas com outra substância psicoativa na forma como era significado pelos sujeitos demonstra uma separação realizada entre os usuários de drogas: aqueles que já controlaram a dependência química e aqueles que ainda a ela estão submetidos. Pois, de acordo com suas explicaçóes, a ayahuasca pode virar droga, dependendo da forma como é agenciada pelo sujeito. Esse agenciamento pode se caracterizar pela ingestão da bebida apenas para "curtir" seus efeitos, sem que o sujeito se engaje na reflexão íntima e na avaliação de si mesmo, comportamentos que transformam a substância psicoativa no sacramento do Santo Daime. Portanto, o agenciamento que o sujeito faz da substância pode reverberar sua cura e pode igualmente reverberar a permanência e progressão do uso de drogas e da dependência química. Para complementar essa compreensão, o fato de ingerir a ayahuasca periodicamente não estremece o entendimento de que os participantes estejam abstinentes, sugerindo novamente que o estatuto de droga de uma substância define-se pelo agenciamento que o sujeito faz dela (Vargas, 2005).

Se, por um lado, na concepçáo da ICNV, a cura ocorre em um enquadramento ritual a partir da ingestão da ayahuasca tornada sacramento do Daime, que determina necessariamente uma experiência específica, por outro, essa experiência deve repercutir no abandono do uso de drogas como uma mudança abrupta, repentina e dramática que, por sua vez, desdobra outra concepção de cura, concebida em um aspecto mais amplo, como uma reforma do sujeito em sua performance na sociedade e em um trabalho constante de sua dimensão espiritual. A efetivação da cura adquire aspectos centrais na marcação do distanciamento entre as instituiçóes, visto que o $\mathrm{AA}$ e a Cravi não determinam um momento definido nem uma experiência culminante. No entanto, o entendimento de que a cura deve ser um trabalho constante, intensivo e extensivamente realizado por toda a vida é uma concepção partilhada por todas as instituiçóes, como vimos na discussão anterior, definida pelo monopólio da interpretação medicalizante e biomédica.

Este trabalho constante é definido pelos códigos culturais de cada terapêutica e delimita aos sujeitos uma abordagem do mundo e da manipulação do quotidiano. Emerge, assim, uma "performance de atualização da cura", categoria preenchida diferentemente de acordo com cada projeto terapêutico e constituída por diferentes práticas, mas que possui os fins comuns de afastamento das drogas e manutenção 
da abstinência. Por conseguinte, as diferenças diminuem em relevância, se analisadas em relação à construçáo da identidade de dependente químico constituída pela lógica absenteísta, tornando ainda mais relevante o conhecimento de como tem sido imbuído de poder o discurso social hegemônico que tem definido e regulado o fenômeno das drogas. Esta hegemonia funde os projetos terapêuticos específicos contornando um outro mais amplo, demonstrando seu poder de disposição de experiências singulares, que têm sido por ele regradas, reconstituídas e transformadas.

A experiência institucional viabiliza uma incorporação desses valores, que implica uma reestruturação inclinada através da apropriaçáo de um haver, de um capital, permitindo incluir os projetos terapêuticos no interior de uma noção de "habitus ${ }^{10}$ terapêutico". Trata-se, dessa forma, de possibilitar que as pessoas se apropriem desse habitus através de um "processo de terapeutização". A incorporação do habitus envolve o sujeito em sua complexidade e, assim, além do controle de uma doença, também envolve uma (re)configuraçáo desse sujeito, cuja base é um projeto de ser, codificado e sustentado em uma noção de identidade de "dependente químico". Nesses projetos, as trajetórias se cruzam e a ressignificação das experiências de todas as pessoas é feita conjuntamente. "Só muda o corpo, as histórias são as mesmas", diz um dos monitores da Cravi. Com efeito, histórias de vida são reinterpretadas em uma história geral de todos os indivíduos.

Náo podemos considerar, contudo, uma relação unilateral entre a pessoa e a instituição. Para o projeto de terapeutização se viabilizar, são de importância fundamental as sociabilidades em curso nos processos transcorridos a partir das vivências institucionais, aspecto fundamental neste jogo, como veremos a seguir.

\section{Atuação e sociabilidade}

Diana usou muitas drogas e cheirou muita cocaína - a sua "droga de preferência" - durante três anos. Ao casar-se, aos 18 anos, interrompeu o uso e teve seu primeiro filho: "Mas este parar me remeteu, anos depois, nossa...”. Durante nossa conversa, Diana enfatizou que parou com a sua "droga de preferência, mas não se tratou". Era fim de semana, churrasco com os amigos, tomava cervejinha, caipirinha: "Eu parei com a minha droga de preferência, mas náo parei com o cigarrinho, com a cervejinha, o vinhozinho... tudo inho" (grifo meu, enfatizando uma ênfase na própria fala). Ao narrar esta passagem, Diana olhou para mim ironicamente. Diana é "do interior" e possui um sotaque bastante forte, diferente dos curitibanos, acentuando as ironias que ela constantemente fazia. Talvez devido a essa diferença, ao menos um dos fatores certamente era esse, eu rapidamente aprendi a notar o que "Diana realmente queria dizer", enquanto estava, referencialmen$\mathrm{te}^{11}$, articulando suas frases.

Os significados das falas emergem do processo dialógico em que este ato está envolvido (Cardoso, 2007). De acordo com Langdon (1999), o ato performático é situado em um contexto particular e construído pelos participantes, contudo, como categoria, distingue-se pela função expressiva ou poética: "a função poética ressalta o modo de expressar a mensagem e não o conteúdo da mensagem" (Op. cit., p. 25). Dessa forma, o poético não é apenas uma função da linguagem, pois envolve "uma compreensão da cultura enquanto performativa, na qual 'coisas', atos, práticas, ideologias, etc. adquirem significados no uso". (Cardoso, 2007, p. 15). Os significados das interpretaçôes de Diana sobre usos de drogas e dependência química emergem tanto do conteúdo representacional quanto da forma poética com que ela se expressava.

A força performativa de uma expressão vo- 
cal pode incluir uma transformaçáo do relacionamento entre entrevistador e respondente (Briggs, 1999). Afinal, a narrativa envolve uma negociação do evento através de relaçôes dialógicas (Bauman; Briggs, 1990) e, nesse sentido, é criada através da interação social (Langdon, 1996). Indo mais adiante, Groisman (2007) considera que

[...] os protagonistas dos discursos são todos os envolvidos na conversa, incluindo aqueles que estão ausentes, mas efetivamente estão ativos no circuito, ou "rede", de trocas - e que transcende em muito as "assinaturas" no que se poderia chamar de livro presencial daquele encontro (p. 15).

Ao falar em protagonistas, o autor procura enfatizar que a voz de uma pessoa articula sempre e dialoga, mesmo que não presencialmente, com outras vozes relevantes, de certa forma onipresentes. Em sentido próximo, o que é dito nunca é dito somente para os presentes. Diana estava se referindo, na verdade, a ela, a mim e a todos os outros dependentes químicos, como explico a seguir através da reconstituição de uma cena de interação que tivemos, anterior a esse momento da entrevista no qual Diana deu o que considerei uma "indireta", em meio a outros conteúdos de seu depoimento.

Cláudio, Diana e eu estávamos tomando café em uma padaria, como sempre fazíamos antes de ir à casa masculina. Eles começaram a falar para combinarmos de sair, de jantar, pois havia muitos lugares em Curitiba que, segundo eles, eu deveria conhecer, já que eu não conhecia nada. Eu concordei, animada, e comentei que abrira um bar "bem legal" ao lado da casa de estudantes em que eu me hospedara, e que eu estava frequentando por ter conhecido as garotas que são donas do bar, acrescentando que eu sentia falta dos meus amigos para sentar e tomar uma cerveja. Então, Cláudio me per- guntou se eu bebia. Respondi que sim, que às vezes gosto de tomar uma cervejinha e de fumar um cigarrinho. Cláudio e Diana começaram a questionar a forma como eu bebo. Como, com quem, em que situaçóes... Então a conversa tomou um rumo no sentido de me informar que eu sou de fato "dependente química". Eles começaram a questionar se já usei outras drogas, quais, e eu continuei contando. Então, Cláudio falou que entre minhas escolhas já estava definido que o álcool era a minha "droga de preferência”. Cláudio me falou, ainda, que se eu não parasse de beber, seria uma senhora de 40 anos bebendo em casa.

A referência ao tudo inho que Diana usou em sua fala referia-se à banalidade com que eu comentei o meu uso de drogas e, em suas palavras, tudo inho remeteu-a a uma recaída porque, embora tivesse parado com a sua "droga de preferência", não parou com a cervejinha, o vinhozinho e, assim, tomar uma cervejinha e fumar um cigarrinho, como eu fazia, não eram atos sem graves consequências, no meu caso particular e no dela, como me falou Cláudio durante a entrevista:

Eu já fiquei muito preocupado com você em relação ao que você me contou, algumas coisas da sua vida, eu me vi um pouquinho ali: nossa, essa aí... Não queria ser grosseiro nem invadir tua vida, teu espaço, mas os conselhos que eu te falei foi pra direcionar um pouquinho as tuas ideias.

Nesse sentido, Diana estava expressando a noção da "doença incurável" que é a "dependência química", e que o "dependente químico" está sempre sujeito a uma recaída, ou, como no meu caso, que (ainda) não havia entrado em tratamento, a uma progressão (inevitável) do uso. Cláudio se referia à nossa identificação como "dependentes químicos". Esses episódios recém-narrados demonstram o entendimento comum que os sujeitos têm sobre si mesmos. 
IO2 | JACQUELINE SCHNEIDER

São expressóes de entendimentos que estimulam a incorporaçáo e o reforço de uma identidade, e, assim, estimulam a fundamentação do próprio projeto de ser no mundo através da prática da abstinência.

Contudo, se a identidade está em jogo na relacionalidade entre pares, para que isso aconteça, a pessoa deve ter vivido "lá", no "mundo das drogas": "É incrível, um drogado cria um mundo só deles, uma sociedade só deles, não tem um normal perto, nunca”, explica Júlia, uma mulher que estava em tratamento na Cravi há aproximadamente dois meses. Essa noção de mundo, trazida por Júlia, que os sujeitos necessitam ter experimentado, é condição para que o sujeito seja legitimado como tal. Portanto, as provas da vivência no mundo das drogas adquirem a conotação de ser um haver, um "capital", no sentido de Bourdieu (1989), ou seja, um habitus. Enquanto "capital", torna-se um saber-poder que a pessoa tem à mão de forma acessível e, assim, pode acioná-lo.

Possivelmente, aí está uma das dimensões da necessidade de um monitoramento e de promover formas de identificação. A criação de um habitus de uso de drogas entre as sociabilidades envolvidas sugere um olhar excludente das diferenças entre práticas que consideramos, em termos éticos, expressivamente diferenciadas em termos de contextos sociais de usos e em termos de subjetividades que usam (Velho, 2003; Soares, 1993). Dessa forma, o habitus de uso de drogas colabora com e é englobado pelo habitus do projeto de identidade.

As vivências comuns no "mundo das drogas" partilhadas no interior dos sistemas são fundamentais para a sustentação das representações e das práticas em torno de ser e saber-se dependente químico. Assim, se constituir-se como sujeito comporta a organização da própria experiência, também significa ser reconhecido entre os pares por essa experiência (Hartmann, 2007). Nesse sentido, a legitimação da (re) construção do sujeito como dependente químico passa necessariamente pela demonstração de histórias vividas no mundo em questão. As narrativas de lembranças das experiências do "mundo das drogas" e as características da identidade de dependente químico compartilhadas nos momentos de brincadeira e de intimidade moldam as interpretaçóes de si mesmo.

Essa legitimação também deve passar, como pude perceber, pela relação com os familiares. A necessidade dos papéis sociais da mãe e do pai em contextos ocidentais já foi enfatizada por Strathern (1995). Segundo a autora, ao colocar em questáo as representaçóes de parentesco, o que está em jogo é a própria ordem social. Cléber foi uma das pessoas que conheci em campo em busca do abandono do uso de crack. Tive a oportunidade de conviver com ele nos trabalhos de cura de que participava e nas tardes de "triagem" para a avaliação de usuários de drogas que procuravam a ICNV. Oficialmente, ele não precisava mais ir às triagens. Contudo, permanecia indo. Nesses momentos, estava sempre acompanhado da mãe e, em uma ocasião, de uma prima. A mãe não queria participar dos trabalhos, pois havia recentemente sofrido um derrame. Contudo, em um dos trabalhos de cura, ela participou sentada ao meu lado, e enquanto o ritual não começava, ela comentou que "agora" sabia do problema do seu filho.

Conforme percebi implicitamente em suas falas, embora não haja, nesta passagem, uma relação direta que pudesse ser evidentemente interpretada como tal, acreditei que a sua presença estava sendo fundamental para Cléber "aceitar" que era dependente do crack. Em um dos grupos terapêuticos da Cravi do qual participei, os residentes da casa masculina deveriam dramatizar os "sentimentos" que apareceram com maior frequência na atividade da semana anterior, chamada "páginas da vida". Tratava-se de descrever sentimentos, entre outras coisas que não pude verificar. Entre os muito citados, 
como raiva e arrependimento, estava recorrentemente citada a frustração de não ter visita. Especialmente aos domingos os familiares podiam visitar os residentes. Lá podiam passar o dia e fazer algo específico, como um churrasco, entre outras atividades. Como percebi nas falas de alguns residentes, esses dias eram esperados com uma expectativa sobre quem viria de suas famílias para vê-los.

De acordo com Souza (1998), a sustentação de uma versão do fato e de uma autoimagem é garantida através da colaboração de outros tidos como significativos, além da necessária confiança na continuidade dessa colaboração. Ser reconhecido pela transformação como um "outro transformado", diferente daquele que vivia no mundo das drogas e atualizava essas experiências, é um veículo importante para afirmar a nova condição. É uma legitimação que permite ao sujeito se reconhecer na (re)ordenação de suas experiências, agora condensadas em um projeto que lhe permitirá passar para a "ordem social”, como referiu Strathern (1995) através dos papéis sociais da mãe e do pai. Para que uma autorrepresentação ligada à (re)construção de uma identidade possa ser dotada subjetivamente de sentido, deve ser reconhecida por outros atores do grupo social (Souza, 1998).

Desta discussão, percebemos que o projeto de ser dependente químico, para se efetivar, está vinculado às negociaçóes que compóem as experiências de sociabilidade entre pares e nas relaçóes com os "outros tornados significativos". Como projeto individual, só pode ser sustentado na medida em que se reconhece e se constrói a partir do jogo simbólico posto em curso nos projetos institucionais. A manipulação dos valores a ele associado e as trajetórias propícias a defini-lo são sustentadas com base nas experiências de sociabilidade, na cumplicidade das brincadeiras que só podem ser entendidas enquanto se reconhecem os valores e noçóes pertinentes a esses projetos, mas que precisam de um reconhecimento externo a esse novo grupo de pertença social, através dos papéis centrais das representaçóes de parentesco. Portanto, a partir das expressóes das representaçóes que envolvem os valores dos projetos terapêuticos, a expressão de depoimentos de trajetórias que só podem se realizar e se legitimar a partir de relatos experienciais do "mundo das drogas", emerge a conjuntura possibilitadora do "ser dependente químico", que tem também como elementos atuantes o olhar sobre si, expresso e manipulado nas falas sobre os outros e nas falas sobre si.

\section{Falas sobre os outros e falas sobre si}

Há aproximadamente oito anos Jaime era um participante ativo do AA em que tive a oportunidade de presenciar uma reunião dirigida por ele. Entrevistei-o ao encontrá-lo logo no dia seguinte, conforme combinado, na frente da igreja sede do grupo de AA em que nos conhecemos. Fomos caminhando até a praça onde sentaríamos para conversar. No caminho, passamos por um grupo de pessoas sentadas no chão, algumas deitadas, bastante sujas e com garrafas de bebida. Depois que passamos, Jaime comentou que eles eram "dependentes químicos". Durante a entrevista, enquanto comentava sobre o "fundo do poço", remeteu-se novamente àquelas pessoas, dizendo que aquele era o fundo do poço delas. Durante a realização desse evento, fomos interrompidos por um homem que passava e nos pediu um real. Jaime falou que "entendia" e que o dinheiro era para comprar bebida. A linguagem "é um movimento que tem uma meta e um efeito; no fundo, é sempre um instrumento de ação. Mas age exprimindo ideias, sentimentos que as palavras traduzem externamente e substantivam" (Mauss, 2001, p. 230).

A referência de Jaime aos (outros) "dependentes químicos", nos momentos anteriores à entrevista, chama a atenção na medida em que 
havíamos feito um acordo de que eu buscava, com a entrevista, narrativas de suas experiências relacionadas ao uso de drogas, conforme combinação no encontro que realizamos no AA. Nesse sentido, a relação reflexiva entre a fala e o contexto (Duranti; Goodwin, 1992) condiciona as falas de Jaime. A intencionalidade de Jaime em suas falas chama a atenção na medida em que são sinalizadas ${ }^{12}$, interrompendo o fluxo da conversa que estávamos tendo enquanto caminhávamos e, posteriormente, comentando sobre o alcoolismo a partir de uma intervenção externa - o homem pedindo dinheiro. Há muito tempo palavras e coisas perderam a relação (Foucault, 2002). Ou seja, as palavras só fazem sentido de acordo com os agenciamentos através dos quais os atores as mobilizam, através da intenção e da reflexividade. É decorrente dessas duas atitudes um monitoramento em torno de falar sobre os outros dependentes químicos e das características que deles fazem parte, de forma a demonstrar para outrem o uso de drogas, movimentado de forma a concretizar sentidos que devem ser transmitidos.

Nessa direção, é possível considerar um agenciamento específico de palavras na referência aos outros dependentes químicos, com uma meta específica da produção de uma identificação e da ilustração daquilo que se quer dizer a outrem e um "efeito" de fortalecimento da própria identidade e das qualidades que a definem.

Júlia relata seu medo de sair da Cravi para passar o fim de semana com o marido - também residente da Cravi masculina -, seu filho e sogros:

Jacque, parece que é uma coisa mais forte que a gente. Como a Keila, a Keila saiu e não voltou até agora, quem disse que a Keila tava... ela sempre fazia devocional, sempre orando, meu Deus, não dá pra acreditar que essa menina usou droga um dia, que ela era da igreja. Mas olha só, ela era tão forte, tão forte, tão forte. Se ela não voltou provavelmente ele [o marido de Keila que estava na Cravi masculina] também não. Então tô com medo, porque ela, tão forte, se mostrava tão forte assim pra gente, então imagine eu que sou muito... sabe... (grifos meus).

As falas sobre os outros sujeitos remetem a si mesmos, na mesma medida em que reforçam através da expressão um olhar sobre si: saber que é difícil parar, saber que se está sujeito a uma recaída, se há uma aproximação com "hábitos, pessoas e lugares" que fizeram parte da época do uso de drogas:

Que nem chegou a menina nova, eu sei que ela era lá da vila, ela e o marido dela, a gente usava junto, foi eu ver ela, na hora me veio aquilo, eu me vi junto com eles, usando lá, como antes. Me veio na cabeça, parecia muito real, até a sensação, na hora, não sei se você reparou... Então se eu chegar lá na minha vila onde eu moro, na frente, no lugar onde eu usei, vai dá na hora aquela vontade e aí não vai ter nada que me segure. (Júlia, grifo meu).

Falar da "menina nova" é falar de si mesma na época do uso. Júlia se imagina no "cenário", no "lugar" em que usava drogas. As falas sobre Keila e sobre a menina nova permitem repensar sobre si mesma, lembrar de experiências passadas, recontextualizando-as, levando aos seus primeiros marcos, e incluí-las em um novo conjunto de expectativas e relaçôes (Duranti; Goodwin, 1992). A orientação do "eu" como um projeto de constituição de uma identidade tem como um dos fundamentos as práticas dos outros, que trazem para a imaginação um passado, reinterpretado, e a monitoração de si mesmo.

Falar sobre o outro é relembrar um passado - partilhado ou não - em que estão as experiências de uso e os contextos que essas experiências envolvem. A partir dessas lembranças, o 
sujeito procura situar-se atualmente em relação a elas, a partir do estabelecimento de um monitoramento de si mesmo através da reflexão sobre o outro. Essa é uma dinâmica presente que permeia as referências aos outros:

Ter que assaltar pra sustentar o vício. Eu não cheguei a me vender, mas coisas piores eu já fiz, tirar o que é dos outros [...] porque não tem como, não tem como você manter um trabalho e usar o crack. No começo você até consegue, uma hora fode tudo. Náo vê a nossa amiga Aline? Ela trabalhava num banco, ela ganhava super bem, ela trabalhava de dia, usava de noite, trabalhava de dia, usava de noite. Chegou um dia que ela não aguentou (Júlia, grifo meu).

Na situação seguinte, é possível refletir novamente sobre a monitoração e a identificação acionadas em relação às referências aos outros. Eduarda - uma residente da Cravi recém-chegada - e eu estávamos sentadas no grande sofá em L que fica no pátio da casa feminina. Enquanto ela tricotava, interrompeu a conversa que estávamos tendo para olhar o relógio. Eduarda começou a falar que estava preocupada com Aline, pois eram quase 5 horas da tarde e ela ainda não havia voltado da "socialização" do fim de semana. Há uma regra na Cravi que estabelece que o residente só pode voltar até as 5 horas da tarde de segunda, após ter passado o fim de semana fora da casa. Eduarda estava preocupada se Aline voltaria para continuar o tratamento, "pois é uma característica de todo dependente químico não terminar nada que começa". Eduarda falava, rindo, que ia "terminar" de tricotar.

Maluf (2003) considera diferentes níveis de enunciados narrativos que podem emergir em uma mesma interação. Nessa perspectiva a narrativa é compreendida de forma ampla e não apenas como um gênero do discurso verbal, mas também como encadeamento de sentido apreendido no nível consciente ou inconsciente. Portanto, Maluf inclui no que nomeia como "níveis narrativos" (Op. cit., p. 12) diferentes formas de expressão além da oralidade, como, por exemplo, o corpo, a gestualidade e os mediadores simbólicos. Eduarda continuou, rindo, na sua fala, no seu tricô, demonstrando com a prática do corpo um desejo de atualizar aquilo que poderia ajudá-la a controlar sua "dependência química”. Agenciando brincadeiras de forma a colocá-las em relevo, indicou o desejo de terminar a peça que tricotava. Ou seja, conjuntamente ao monitoramento, interagindo estreitamente com ele, aparece a dimensão do cuidado com o outro - Aline, que não voltava - e consigo mesma - "terminar" o tricô, para não agir como todo dependente químico age, não terminando nada do que começa. Afinal, há uma linha muito tênue que separa "monitoramento" de "cuidado".

Chamando Lorenço ao diálogo, durante a experiência de campo na instituição, percebi que nos momentos anteriores ao início dos trabalhos havia uma forte sociabilidade, caracterizada na interação entre os recém-chegados e as pessoas que já participavam da igreja. Lorenço, em um dos dias de "triagem" em que eu estava presente, enquanto não havia nenhuma pessoa na busca pelo trabalho de cura demandando sua atenção, iniciou uma fala sobre Cléber, enquanto conversávamos. Falou que ele estava há algum tempo em uma dinâmica de tentativas de parada e de retorno ao uso. Acrescentou que estava fazendo recomendaçóes a ele para participar de todos os trabalhos, esperando que ficasse "firme". A descrição das atividades humanas requer familiaridade com as formas de vida expressas naquelas atividades (Giddens, 1989) e, assim, sua fala remete à própria dinâmica de Lorenço em sua relação com a ICNV. Ele havia realizado sua cura naquela igreja e, desde entáo, continuou participando dela. Uma possibilidade interpretativa é que Loren- 
I06 | JACQUELINE SCHNEIDER

ço estende a esse sujeito seu entendimento de como ficar "firme" e longe das drogas, atualizando a si mesmo sua interpretação. Retomo aqui a fala de Diana:

E aí eu tinha seis dias de Chave eu e uma menina, consegui achar uma pior que eu, sei que foi muito importante pra mim essa minha saída, esse lapso que eu tive, porque foi ali que eu vi realmente que eu não era diferente de ninguém. Porque eu sempre tive aquela coisa: ai, eu não sou igual àquela neguinha. Tem uma diferença bem grande social aqui dentro da Cravi feminina, eu cheguei ali, meu Deus, essas neguinha, cheia de piolho, eu não sou assim! Só era assim, era pior do que elas e não via, porque meu ego não deixava. A saída que eu tive aí eu fiquei dois dias na rua, eu náo tinha dinheiro. Vi porque eu tava suja, em situação de rua. Sabe... Tava na mesma situação que eu vi as meninas chegarem à casa feminina. Enquanto antes na verdade era tudo muito fácil pra mim. Mas chegou um momento que botei tudo fora. Aí fui usar droga na condiçãao mais comum do usuário de drogas, à mercê da sociedade. E via que as pessoas passavam por mim e, nossa, que drogada! Então, foi tudo importante pra mim, enquanto antes na verdade era uma imagem que náo existia (grifos meus).

Diana, considerando-se antes "diferente" das outras residentes, logo passa a se considerar uma "igual", ao mesmo tempo em que avalia uma imagem que não existia e assume a identidade compartilhada com as "neguinhas".

Em uma ocasiáo, participei de uma atividade de uma das psicólogas com as "adolescentes"13. Inicialmente, mostrou-se uma caixa de sapatos, perguntando se as garotas adivinhavam o que havia ali. A caixa ficou no centro do círculo formado entre nós, sem ter seu conteúdo revelado. A atividade consistia na leitura de frases realizada pela psicóloga, em que se con- tava uma história na qual eram citadas várias qualidades, como "responsável”, “amiga”, “carinhosa". Quem estivesse com a bolinha na mão passava para a outra quando a psicóloga falava algo como: "passe para uma pessoa que você considera carinhosa!" E, então, sucessivamente, até que acabassem as frases e as qualidades descritas. Ao final, a garota que tivesse recebido mais vezes a bolinha ganhava a caixa. A caixa estava cheia de doces.

Dessa forma, expressa-se o reconhecimento de qualidades do outro, que visa, em minha leitura realizada a partir de todo o contexto onde este jogo foi possível, auxiliar a construção de uma identidade, reforçar determinados valores e recompensar quem satisfaz expectativas. Portanto, as falas sobre os outros, no sentido de uma manifestação pública de apreço e opinião sobre esses outros, não necessariamente se dão através de um "diálogo oculto" 14 , como vimos nas falas reproduzidas acima, nas quais as pessoas referenciadas não estavam presentes. Nesse sentido, considero o jogo da bolinha como um importante jogo de expressão. Esse jogo configura-se como uma trama explícita de circulação de valores, de certa forma demarcando expectativas e diferentes níveis de incorporação da identidade. De acordo com Giddens (1989), na maioria das esferas da vida, o âmbito do poder de controle limita-se aos contextos imediatos de ação e interação. Nesse sentido, essas "falas presenciais" podem ser interpretadas com o sentido de fortalecer, através do controle, a identidade grupal de uma forma pública e institucionalizada. Contudo, para além da dimensão do fortalecimento está a dimensão do controle da incorporaçáo a partir de um jogo que interpreto como "competição".

A ação é um processo contínuo em que uma monitoraçáo reflexiva é fundamental para atividades que envolvem controle $(O p$. cit.) e, nesse sentido, o cuidado e o monitoramento fazem parte de um jogo que podemos entender 
como um "sistema de acusaçóes" 15 . Um sistema como esse pode "desempenhar funçóes de delimitar fronteiras e exorcizar dificuldades" (Velho, 2004, p. 57). As açôes de monitoramento se dão através das falas sobre si e das falas sobre os outros, como um diálogo oculto, ou como diálogos presenciais. $\mathrm{Na}$ gama dos diálogos presenciais, há expressão ampla de um sistema de acusaçóes. Por exemplo, existe uma reunião, todos os domingos, na casa masculina da Cravi em que costumam estar presentes todos os residentes. Nessa reunião são lidos os "relatórios". Há um conjunto de regras fixas na instituição, e toda a pessoa que infrinja alguma(s) dela(s) está passível de ser "relatada" por outra. A infração às regras é em geral tomada como a infração dos valores delimitadores de uma versão da realidade.

Ser acusada de "responsável", "amiga" e "carinhosa" são fatores que reforçam a reconstrução da identidade. Considerar uma pessoa responsável pode ser reconhecer a pessoa em seu processo de tratamento e na evolução para a sua recuperação. Nesse sentido, o conteúdo da caixa como recompensa sintetiza níveis de "ajustamento" e, na medida em que implica escolha, um caminho de expressão para identificar os que não estão devidamente "ajustados". Portanto, a orientação do "eu" como um projeto de constituiçáo de uma identidade tem como uma possibilidade de realização as práticas dos outros que trazem para a imaginação um passado, agora reinterpretado, podendo levar à monitoração de si mesmo. Através dessa atividade, em suma, aciona-se um mecanismo para o "novo eu" adquirir realidade e poder deixar distante aquele "eu antigo".

A "acusação" deixa de ser exclusiva da denúncia pública de indivíduos desviantes para se tornar um processo importante no jogo de incorporação do habitus terapêutico. Nesse sentido, uma acusaçáo evoca um investimento denso no sistema de expectativas quanto aos comportamentos socialmente controlados e às noçôes que a eles se relacionam. Como podemos entender esse sistema de acusaçóes não marca necessariamente uma diferença, podendo indicar um olhar sobre o outro sistematizado de uma maneira especular, de acordo com o desejo de identificação consigo mesmo manifestado pelo sujeito.

O discurso da identidade está localizado no plano das aproximaçôes, das comparaçôes, das vontades e das representaçôes (Rodrigues; Caroso, 1998). De acordo com os autores, é preciso entender as relaçôes entre o que é semelhante e o que é diferente e perceber como essas instâncias se articulam em discursos diferentes. Analisando essa articulação, a dicotomia que trabalhamos entre o "si" e o "outro" não é tão simples como aparenta, pois as falas sobre si incluem as falas sobre os outros, se esses outros são também "dependentes químicos", e as falas sobre os outros incluem as falas sobre todos os outros que não são dependentes químicos, inclusive aqueles que podem estar "em tratamento", mas que não são reconhecidos pelos sujeitos como pertencentes à categoria dos dependentes químicos. Este era o caso de Viviane. Mais de uma das residentes da casa feminina me falou que Viviane não era dependente química. Na verdade, sua máe estava na Alemanha e ela morava com a avó. Por alguma razão que elas não souberam ou não me disseram, Viviane estava lá. Eduarda diz, em tom de banalidade e descrença: "ah, ela diz que já cheirou cocaína...”.

A realidade de si mesmo ou a consciência de estar no mundo é formada dentro de uma realidade experiencial composta de parceiros com os quais os indivíduos assumem um grau de compartilhamento da experiência e uma estrutura dividida de entendimentos através dos quais se tornam conscientes de si mesmos e das experiências dos outros (Kapferer, 1986). O que poderíamos chamar de "agências in- 
IO8 | JACQUELINE SCHNEIDER

dividuais" se apresenta mais como "agências transindividuais", desdobrando-se em "agências coletivas". Assim, nas tramas terapêuticas realiza-se um jogo, propiciador de um vínculo entre representaçóes e práticas que fornecem coerência e significado através da construção de uma "identidade de dependente químico" a eventos perturbatórios que envolvem o uso de drogas. Esse processo se dá através da vinculação de um "projeto de identidade" engendrado em um sistema complexo de sociabilidade, envolvendo uma interação com os outros significativos e um sistema classificatório-acusatório.

\section{Consideraçóes finais}

Como vimos, as instituições terapêuticas que analisamos definem uma série de características comuns e algumas diferenças. Entre as aproximaçóes, destaquei a presença de acentuada dimensão espiritual, a importância das figuras transitivas - líderes institucionais que haviam controlado suas próprias dependências químicas e que, por isso, traziam consigo os signos da doença e da cura, condição que legitimava seus papéis de curadores - e, por fim, a presença de um léxico específico que circulava nas e entre as instituiçôes, constituindo-se como categorias centrais que organizavam as experiências dos sujeitos. No que concerne aos distanciamentos, encontramos diferenças nas práticas de cura, mas que, como concepção, circunscreviam todas à categoria que nomeei de "performance de atualização da cura", uma necessidade de mantê-la através de práticas que determinavam uma abordagem de mundo e uma manipulação do cotidiano diferenciadas de acordo com a instituição, mas que eram igualmente pautadas pelo afastamento das drogas que o sujeito deveria sustentar.

Portanto, aproximaçóes e distanciamentos entre as instituiçôes terapêuticas demonstram o entrecruzamento com o modelo hegemônico de medicalização do uso de drogas que repercute na lógica absenteísta, definindo um modelo de doença incurável que culmina na noção de dependência química. Jogando com essas noções, as instituiçôes vão estabelecer um projeto terapêutico que vai definir para os usuários de drogas que nelas se encontrem, em maior ou menor medida, com maior ou menor sucesso, a reorganização de suas experiências, e a inclinação à metamorfose a partir de vivências institucionais.

Essas vivências se desdobram a partir de uma série de aspectos singulares. Dentre eles, devemos mencionar a ênfase nos jogos de identificação e legitimação dos sujeitos como dependentes químicos que se revelam nas sociabilidades cotidianas. As representaçóes institucionais articuladas às características específicas que apresentam em conjunto com as sociabilidades mencionadas engendram um jogo que define o caráter das experiências vivenciadas nos contextos institucionais como um processo de construção e afirmação, ao que parece, de uma identidade de dependente químico.

\section{Therapeutic Entanglement: a Study on the} (Re)Constitution of the Identity of Drug Users

abstract This paper discusses the experiences of drug user in the following institutions located in the metropolian area of Curitiba, in the state of $\mathrm{Pa}$ raná: the Santo Daime church Céu da Nova Vida, the therapeutic community Água da Vida, and an Alcoholics Anonymous group. Based on ethnographic experience, I point out that these sites involve a series of characteristics, representations, and sociabilities that set in course the construction of a 'chemical dependent identity' and, through it, the more or less successful 'internalization of a habitus'. As a result of this process, I suggest that these experiences tend to metamorphosis, defining ways of being in the world made possible by the engagement of 
the subjects with what are understood as therapeutic projects.

keywords Drugs. Therapeutics. Experience. Identity. Metamorphosis.

\section{Notas}

1. Este artigo é um desdobramento de discussóes levantadas em minha dissertaçáo de mestrado (Schneider, 2009).

2. Modernamente o uso e drogas é assediado por uma intensa disputa emergida a partir de duas orientaçóes antagônicas que visam regrar este fenômeno: de um lado, o discurso absenteísta: agentes sociais que defendem a proibição e a repressão absolutas ao consumo; de outro, o discurso reducionista: agentes sociais que argumentam a favor de políticas de redução de danos que visam favorecer práticas que regulem de alguma forma o consumo de drogas, tendência essa, portanto, que se distancia da proibiçáo e da abstinência.

3. "Modalidade de tratamento" para usuários de drogas é uma categoria nativa. Refere-se aos distintos formatos e programas de tratamento que uma instituição pode ter para pôr em curso o "tratamento" e/ou a "recuperaçáa".

4. De acordo com Groisman (2009), as vertentes mais conhecidas e reconhecidas classificadas provisoriamente como religiôes ayahuasqueiras brasileiras são as seguintes: (1) grupos cujos ramos mais visíveis são o "Alto Santo" e Santo Daime/CEFLURIS; (2) a Barquinha e (3) a Terceira vertente, organizada em torno da entidade nomeada Centro Beneficente Espírita "União do Vegetal". Cada qual de suas vertentes tem seus respectivos fundadores, embora as vertentes 1 e 2 compartilhem da fundação realizada por Irineu Serra, mas também se diferem, pois a Barquinha também tem como fundador Daniel Pereira dos Santos. A mais comum e visível familiaridade entre essas vertentes se refere à utilização da ayahuasca em contexto ritual-religioso, cujas atribuiçōes são propriedades terapêuticas e divinatórias.

5. Padrinho é um termo nativo que se refere ao dirigente e ao coordenador principal dos rituais.

6. Os nomes dos interlocutores foram substituídos por nomes fictícios.

7. Becker (2004) realiza essa discussão refletindo sobre a "linguagem neutra" utilizada por Erving Goffman para se referir às "instituiçóes totais". Como um exemplo, fala do termo "controle escalonado" utilizado por Goffman, ao invés do termo "dominação". O primeiro termo envolve a demonstraçáo de um fato observável, enquanto o segundo inclui um julgamento moral do arranjo de ordenamento. Becker (2004) utiliza sua própria experiência de pesquisa para fazer essas reflexôes sobre a linguagem: "se alguém aceita as categorizações convencionais incorporadas à linguagem comum e ao mundo ordinário pelo qual as instituições e práticas são organizadas no pensamento convencional, se impensadamente se refere a alguém que bebe muito álcool como alcoolista, se trata as pessoas que consomem maconha como aditos, então essa pessoa aceita as ideias que tais palavras, mais, ou menos, a obrigam a aceitar, ideias incorporadas às próprias palavras e às perspectivas a elas associadas. Se alguém que fuma maconha é um 'adito', então essa pessoa fumará incontrolavelmente, será um 'escravo' dessa prática, vai participar de crimes para pagar sua droga e assim por diante. Se alguém utilizar estas palavras para definir a classe de fenômenos que está estudando [...] não encontrará regularidades empíricas sobre as quais fazer generalizaçōes científicas". (Op. cit., p. 109).

8. Embora, como vimos na discussão da última seção, a noção de dependência química conceba uma doença incurável, a noção de cura que descrevo deve ser encarada com flexibilidade, no sentido de que ela define uma resolução de um problema, uma transmutação da experiência através da sua ressignificação possibilitada pela vivência nos projetos terapêuticos e, assim, náo deve ser confundida com uma noção de cura que implique uma eliminação absoluta de sintomas e da própria doença.

9. Essa expressáo segue uma tendência que procura direcionar um olhar para o caráter sacramental do uso ritual da ayahuasca, e dessa forma é uma reação à inclusão desse uso na categoria do que o senso comum entende por drogas, ou seja, substâncias a serem proscritas e criminalizadas (Groisman, 2009).

10. Refiro-me ao conceito de habitus de Pierre Bourdieu, gradativamente elaborado e reelaborado no decurso intelectual do autor, além de ter uma longa tradição. Assim, o conceito foi inovado, abarcando dimensōes tais como a individualidade, a subjetividade, a estrutura, o passado instalado como disposição duradoura. Esse conceito pode ser entendido como um instrumento analítico que ajuda a pensar os elementos da cultura e a mediaçấo com a subjetividade de sujeitos. Mais que um conceito, essa perspectiva propóe uma ruptura com velhas dicotomias tais como mente/cor-

cadernos de campo, São Paulo, n. 19, p. 91-112, 2010 
I I O JACQUELINE SCHNEIDER

po, indivíduo/sociedade, ou seja, pensar os fenômenos sem a exclusão de uma ou outra parte. O habitus, então, "é um conhecimento adquirido e também um haver, um capital, [...] indica a disposição incorporada, quase postural" (Bourdieu, 1989, p. 61).

11. Refiro-me aos modos indexical e referencial da fala (Briggs, 1999). O modo indexical interpreta a fala pronunciada em sua relação com a situação contextual em que ela é expressa. O referencial seria a consideração exclusiva do conteúdo da fala em sua concepção não relacional e destacada da situação em que é proferida.

12. Utilizo esta menção à sinalização de forma análoga à noção de "keing" (Langdon, 1996). Esta noção é uma qualidade dos eventos performáticos: "são momentos de ruptura do fluxo normal de comunicação, momentos que são sinalizados para estabelecer o evento da performance, para chamar a atenção dos participantes para a performance” (Op. cit., p. 27). Na sinalização realizada por Jaime, não se trata propriamente do que podemos considerar como um ato performático nessa perspectiva; contudo, utilizo-me da analogia para expressar principalmente o que se tornou significativo nessa discussão: a interrupção de uma conversa para introduzir categorias e referências nativas.

13. Na Cravi havia uma diferença entre os adultos e os adolescentes, marcada pela delimitação de faixa etária. Adolescentes eram as pessoas até 18 anos, enquanto adultos eram pessoas de 18 anos para cima. Cada grupo tinha atividades próprias, mas também comuns, e se instalavam em dormitórios diferenciados.

14. Utilizo esta expressáo como uma analogia à referência de Crapanzano (1991) ao diálogo oculto. Com esta expressão, o autor se refere aos diálogos próprios ao etnógrafo na apresentação da experiência de campo vivida. Sinteticamente, estes são "diálogos que um participante do diálogo primário tem com um interlocutor que não está presente nesse diálogo primário" (Op. cit., p. 78). De forma similar, utilizo esta ideia para me referir ao diálogo que o sujeito tem comigo o diálogo primário - a respeito de um outro, "real" ou "imaginário", não presente nesse evento de interlocução. Continuando a analogia com as ideias do autor, pontuo uma última colocação: "há que lembrar que qualquer que seja a resistência daqueles com quem conversamos, eles sempre serão um pouco nossa criação, assim como nós somos a deles" (Op. cit., p. 79). Com esta pontuação desejo chamar a atenção para o fato de que, mesmo óbvio, as "falas sobre os outros" que os interlocutores realizam comigo são (ou podem ser) baseadas na imagem que eles "um pouco criam" sobre os outros e sobre mim.

15. Cabe apontar que a temática da "acusação" não é nova na antropologia e evidenciar alguns aspectos importantes para nos ajudar a compreender esses processos sociais. Retomando sinteticamente apenas os autores tornados clássicos da disciplina que se debruçaram sobre o tema: o pioneiro Evans-Pritchard (2005), Mary Douglas (1999) e Max Gluckman (1970), todos verificaram e procuraram compreender as evidências desses processos entre grupos estudados. A partir da leitura das descriçóes dos autores sobre as relaçóes sociais e as "crenças", encaramos as acusaçôes, do que quer que sejam, como acusações morais - acusaçōes que fundam, em um amplo sentido, as relaçóes de desconfiança e, assim, a reflexão e a análise sobre monitoramento e sobre cuidado. Portanto, a temática da acusação se configura como um recurso interessante para o estudo de relaçóes sociais, especialmente nas relaçóes morais, nas relaçóes de controle, nas relações de conflito.

\section{Referências bibliográficas}

BAUMAN, Richard; BRIGGS, Charles. Poetics and Performance as Critical Perspectives on Language and Social Life. Annual Review of Anthropology, Palo Alto, v. 19, p. 58-88, 1990.

BECKER, Howard. As Políticas da Apresentação: Goffman e as Instituiçôes Totais. In: GASTALDO, E. (Org.). Erving Goffman. Desbravador do Cotidiano. Porto Alegre: Tomo Editoria, 2004. p. 101-110.

BOURDIEU, Pierre. Opoder simbólico. Lisboa: DIFEL, 1989.

BRIGGS, Charles. Learning How to Ask. A Sociolinguistic Appraisal of the Role of the Interview in Social Science Research. Cambridge: University Press, 1999.

CAMPOS, Edemilson Antunes de. Contágio, doença e evitação em uma associação de ex-bebedores: o caso dos Alcoólicos Anônimos. Revista de Antropologia, São Paulo, v. 48, n. 1, p. 315-361, 2005.

CAPRARA, Andréa. Médico Ferido: Omolu nos Labirintos da Doença. In: ALVES, P. C. B; RABELO, M. C. (Orgs.). Antropologia da Saúde. Traçando Identidades e Explorando Fronteiras. Rio de Janeiro: Relume-Dumará, 1998. p.123-138.

CARDOSO, Vânia Zikán. Narrar o mundo: estórias do povo da rua e a narração do imprevisível. In: Mana, Rio de Janeiro, v. 13, n.2, p. 317-345, 2007.

CARNEIRO, Henrique. Transformaçóes do Significado da Palavra Droga: das Especiarias Coloniais ao Proibi-

cadernos de campo, São Paulo, n. 19, p. 91-112, 2010 
cionismo Contemporâneo. In: CARNEIRO, H; VENÂNCIO, R. P. (Orgs.). Álcool e Drogas na História do Brasil. São Paulo: Alameda; Belo Horizonte: Editora PUCMinas, 2005. p.11-28.

CRAPANZANO, Vincent. Diálogo. Anuário Antropológico/88, Tempo Brasileiro/Editora da UNB, Rio de Janeiro/Brasília, p. 59-80, 1991.

CRAVALHO, Mark Andrew. De Doente a 'Encantado': o Conceito de Mecanismo de Defesa Constituído Culturalmente e a Experiência de uma Vítima de 'Espírito Mau' em uma Comunidade Rural na Amazônia. In: ALVES, P. C. B; RABELO, M. C. (Orgs.). Antropologia da Saúde. Traçando Identidades e Explorando Fronteiras. Rio de Janeiro: Relume-Dumará, 1998. p. 157-177.

DE ROSE, Isabel Santana. Repensando as fronteiras entre espiritualidade e terapia: reflexôes sobre a cura no Santo Daime. In: Campos (UFPR), Curitiba, v. 17, n.1, p. 35-52, 2006.

DOUGLAS, Mary. Os Lele revisitados, 1987 acusaçóes de feitiçaria à solta. In: Mana, Rio de Janeiro, v. 5 , n. 2, p.7-30, 1999.

DURANTI, Alessandro; GOODWIN, Clarles. Rethinking Context. Language as an Interactive Phenomenon. Cambridge: Cambridge University Press, 1992.

EVANS-PRITCHARD, Edward Evan. Bruxaria, oráculos e magia entre os Azande. Rio de Janeiro: Jorge Zahar Editor, 2005.

FAINZANG, Sylvie. Maladie, identité et guérison dans un groupe d'anciens buveurs: Vie Libre. In : Revue Ethonologie française, v. 11, n.1, Paris: Les presses universitaires de France, p.5-18, 1992. Acesso em: 15 jul. 2009.

FIGUEIRA, Sérvulo Augusto. Notas Introdutórias ao Estudo das Terapêuticas: Lévi-Strauss e Peter Berger. In: (Org.). Sociedade e Doença Mental. Rio de Janeiro: Editora Campus, 1978. p. 87-148.

FOUCAULT, Michel. As palavras e as coisas. Uma arqueologia das ciências humanas. São Paulo: Martins Fontes, 2002.

GIDDENS, Anthony. A constituição da sociedade. São Paulo: Martins Fontes, 1989.

GLUCKMAN, Max. The Logic in Witchcraft. In:__ (Org.). Custom and Conflict in Africa. Oxford: Basil Blackwell, 1970. p. 81-108.

GOOD, Byron. The Heart of What's the Matter: the Semantics of Illness in Iran. In: Culture, Medicine and Psychiatry, Cleveland, v.1, p.25-58, 1977.

GROISMAN, Alberto; SELL, Ari. Healing Power: Cultural Neorophenomenological Therapy of Santo Daime. In: WINKELMAN, M; ANDRITZKY, W. (Orgs.).
Yearbook of Cross-Cultural Medicine and Psychotherapy. Berlim, 1996. p. 241-265.

GROISMAN, Alberto. Interlocuçôes e interlocutores no campo da saúde: considerações sobre noçôes, prescriçóes e estatutos. In: Antropologia em Primeira Mão, Florianópolis, v. 93, p. 1-11, 2007.

Religiōes Enteógenas: Ritual e Saúde entre Participantes do Santo Daime em Santa Catarina. In: ISAÍA, A. C. (Org.). Crenças, Sacralidades e Religiosidades. Florianópolis: Editora Insular, 2009, p.139-158.

HARTMANN, Luciana. As Narrativas Pessoais e a Constituição dos Contadores de Causos como Sujeitos. In: FISCHMANN, F; HARTMANN, L. (Orgs.). Donos da Palavra. Autoria, Performance e Experiência em Narrativas Orais na América do Sul. Santa Maria: Editora da UFSM, 2007. p. 95-130.

KAPFERER, Bruce. Performance and the Structuring of Meaning and Experience. In: TURNER, V; BRUNER, E. (Orgs.). The Anthropology of Experience. Urbana: University of Illinois Press, 1986, p.188-203.

LANGDON, Esther Jean. Performance e preocupaçóes pós-modernas em Antropologia. In: Performáticos, Performance e Sociedade, Brasília, UnB, v. 1, n. 1, p. 23-29, 1996.

. A fixação da narrativa: do mito para a poética de literatura oral. In: Horizontes Antropológicos, Porto Alegre, n.12, p.113-136, 1999.

. Cultura e os Processos de Saúde e Doença. In: Cultura, Saúde e Doença, 2003, Londrina. Annais.... Londrina: MS-UEL-SMAS/PML, 2003. p.91-107.

MAUSS, Marcel. A Prece. In:___ (Org.). Ensaios de Sociologia. São Paulo: Perspectiva, 2001. p.15-29.

MALUF, Sonia Weidner. Mitos Coletivos e Narrativas Pessoais. Cura, Ritual e Trabalho Terapêutico nas Culturas da Nova Era. (manuscrito). 2003

MONTERO, Paula. Da doença à desordem. A magia na Umbanda. Rio de Janeiro: Graal, 1985.

RABELO, Miriam Cristina Marcilio. Religião e cura: algumas reflexôes sobre a experiência religiosa das classes populares urbanas. In: Cadernos de Saúde Pública, Rio de Janeiro, v.9, n.3, p. 316-25, 1993.

RODRIGUES, Núbia; CAROSO, Carlos Alberto. A Idéia de "Sofrimento" e Representaçáo Cultural da Doença na Noção de Pessoa. In: DUARTE, L. F. D; LEAL, O. F. (Orgs.). Doença, Sofrimento, Perturbaçâo. Perspectivas Etnográficas. Rio de Janeiro: Fiocruz, 1998, p.137-150.

SABINO, Nathalí di Martino; CAZENAVE, Sílvia de Oliveira Santos. Comunidades terapêuticas como for-

cadernos de campo, São Paulo, n. 19, p. 91-112, 2010 
I I 2 JACQUELINE SCHNEIDER

ma de tratamento para a dependência de substâncias psicoativas. In: Estudos de Psicologia I, Campinas, v. 22, n.2, p. 157-174, abr/jun, 2005.

SCHNEIDER, Jacqueline. Dos fios quotidianos à trama terapêutica: subjetividade, uso de drogas e experiência. Dissertação (mestrado), Departamento de Antropologia Social, Universidade Federal de Santa Catarina, Florianópolis, 2009.

SOARES, Luiz Eduardo. A Política de Drogas na Agenda Democrática do Século XXI. In: BASTOS, F. I; GONÇALVES, O. D. (Orgs.). Drogas: É legal? Um Debate Autorizado. Rio de Janeiro: Instituto Goethe e Imago, 1993. p.125-141.

SOUZA, Iara Maria de Almeida. Um Retrato de Rose: Consideraçôes sobre Processos Interpretativos e Elaboração de História de Vida. In: DUARTE, L. F. D; LEAL, O. F. (Orgs.). Doença, Sofrimento, Perturbação. Perspectivas Etnográficas. Rio de Janeiro: Fiocruz, 1998. p.151-168.

STRATHERN, Marylin. Necessidade de pais, necessidade de mães. In: Estudos Feministas, Florianópolis, v. 3, n. 2, p.303-329, 1995.

VARGAS, Eduardo Viana. Entre a extensão e a intensida- de: corporalidade, subjetivação e uso de drogas. Tese (Doutorado). , Faculdade de Filosofia e Ciências Humanas, Departamento de Sociologia e Política, Universidade Federal de Minas Gerais, Belo Horizonte, 2001.

Drogas: Armas ou Ferramentas? In: MINAYO, M. C; COIMBRA, C. (Orgs.). Críticas e Atuantes. Ciências Sociais e Humanas em Saúde na América Latina. Rio de Janeiro: Fiocruz, 2005. p. 587-608.

VELHO, Gilberto. Projeto e metamorfose. Antropologia das sociedades complexas. Rio de Janeiro: Jorge Zahar Editor, 2003.

Individualismo e cultura. Notas para uma Antropologia das sociedades contemporâneas. Rio de Janeiro: Jorge Zahar Editor, 2004.

YOUNG, Allan. Some implications of medical believes and practices for Social Anthropology. In: American Anthropologist, Arlington, v.78, n.1, p.5-24, 1976.

\section{autora Jacqueline Schneider \\ Mestre em Antropologia Social / UFSC}

Recebido em 04/03/2010

Aceito para publicação em 20/09/2010 